21.S7

\title{
Influence of Donor Age on the Survival of Human Embryonic Dopaminergic Neural Grafts
}

\author{
T.B. Freeman ${ }^{*+}$, G.M. Nauert ${ }^{* *}$ P.R. Sanberg ${ }^{*}$, J.H. Kordower ${ }^{++}$ \\ Departments of "Neurosurgery and ${ }^{+}$Pharmacology, University of South Florida, Tampa, FL 33606; \\ ${ }^{* *}$ Tampa Women's Health Center, Tampa, FL; ${ }^{++}$Department of Neurological Sciences, \\ Rush Presbyterian Medical Center, Chicago, IL 60606, USA
}

There is substantial variability worldwide in the donor ages utilized in nigral transplantation programs for the treatment of Parkinson's disease. In multiple non-human species, it has been repeatedly demonstrated that optimal graft survival occurs when embryonic nigral neurons are harvested before the period of axonal extension, most likely due to axotomy and cell death of older neurons /1; see 2,3/.

Neurons which form the human substantia nigra develop within the ventricular zone primarily between post-ovulatory (PO) day 33 and $63 / 2,5 /$. The nigrostriatal bundle begins to develop at approximately PO day $56 / 2 /$. From this data it could be predicted that the optimal period for suspension graft survival would occur before PO day $56 / 2,3 /$. Solid grafts in nonhuman species have been found to have a slightly longer donor age "window" for graft harvesting than suspension grafts /see $3 /$.

We compared the ability of solid and suspension grafts of human embryonic dopaminergic neurons at different embryonic ages to survive grafting into 6-OHDA lesioned immunosuppressed rats. Donor age was determined using the atlas of O'Rahilly and Müller /4, also see 2 . Suspension grafts survived best from PO day 37 to 56 with diminishing success through PO day 65. These implants displayed numerous healthy tyrosine-hydroxylase-immunoreactive (TH-ir) neurons which sent extensive neuritic processes into the host striatum. Conversely, suspension grafts of human embryonic dopaminergic neurons survived poorly when the donor age was greater than $\mathrm{PO} 65$ days.

In contrast to suspension grafts, solid implants of human ventral mesencephalic tissue displayed only modest survival of TH-ir neurons derived from younger donors. These grafts also displayed a limited host innervation. Good/ excellent survival of $\mathrm{TH}$-ir neurons was observed in solid grafts employing embryonic donors between PO day 45 and 65 . Only trace numbers of TH-ir neurons were present within grafts derived from $\mathrm{PO} 72$ tissue.

In conclusion, the upper age limit for survival of human embryonic dopaminergic suspension grafts correlates well with the period of development of the human nigrostriatal pathway. Optimal donor ages for human nigral suspension grafts range from PO day 37 to 56 days. The donor age "window" for transplantation of solid human embryonic dopaminergic grafts appears to be extended by about nine days in comparison with suspension grafts. In younger age ranges (less than or equal to 41 days), intraparenchymal suspension nigral grafts survive better than solid grafts. The optimal donor age for intraparenchymal solid grafts ranges from PO day 4565. There appears to be a sharp fall-off in the

SURVIVAL OF INTRAPARENCHYMAL HUMAN EMBRYONIC NEURAL XENOGRAFTS BY AGE

\begin{tabular}{cclll}
\hline $\begin{array}{l}\text { Post Ovulatory } \\
\text { Age (days) }\end{array}$ & $\begin{array}{l}\text { Donor } \\
\text { stage }\end{array}$ & $\begin{array}{l}\text { Foot } \\
\text { Length } \\
(\mathrm{mm})\end{array}$ & $\begin{array}{l}\text { Graft Survival } \\
\text { (Best) } \\
\text { Suspension }\end{array}$ & Solid \\
\hline 33 & 15 & -- & $* * *$ & -- \\
37 & 16 & -- & $* * * *$ & $* *$ \\
41 & 17 & -- & $* * * * *$ & $* * *$ \\
$45-56 \mathrm{~d}$ & $18-23$ & -- & $* * * * *$ & $* * * * *$ \\
57 & -- & 5.5 & $* * *$ & -- \\
65 & -- & 7.5 & $0-* *$ & $* * * *$ \\
72 & -- & 8.5 & 0 & trace \\
& & & & cells \\
\hline
\end{tabular}


number of surviving dopaminergic neurons in both solid and suspension grafts derived from older donors. We suggest that clinical nigral transplant programs for the treatment of Parkinson's disease limit donor age to these dates.

\section{REFERENCES}

1. Björklund A, Stenevi U, Schmidt RH, Dunnett SB Gage FH. Intracerebral grafting of neuronal cell suspensions. I. Introduction and general methods of preparation. Acta Physiol Scand 1983; Suppl 522: 1-7.

2. Freeman TB, Spence MS, Boss BD, Spector DH, Strecker RE, Olanow CW, Kordower JH. Development of dopaminergic neurons in the human substantia nigra. Exp Neurol 1991; 113: 344-353.

3. Freeman TB, Kordower JH. Human cadaver embryonic substantia nigra grafts: effects of ontogeny, preoperative graft preparation and tissue storage. In: Intracerebral Transplantation in Movement Disorders: Experimental Basis and Clinical Experience. Amsterdam: Fernstrom BV, 1991; 15: 163-170.

4. O'Rahilly R, Müller F. Developmental Stages in Human Embryos, Including a Revision of Streeter's "Horizons" and a Survey of the Carnegie Collection. Carnegie Institution of Washington, Publication 637.

5. Verney C, Zecevic N, Nikolic B, Alvarez C, Berger B. Early evidence of catecholaminergic cell groups in 5 and 6-week-old human embryos using tyrosine hydroxylase and dopamine-B-hydroxylase immunocytochemistry. Neurosci Lett 1991; 131: 121-124. 

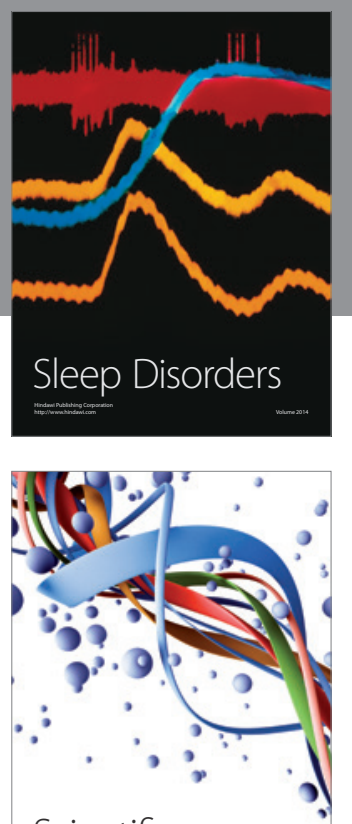

Scientifica
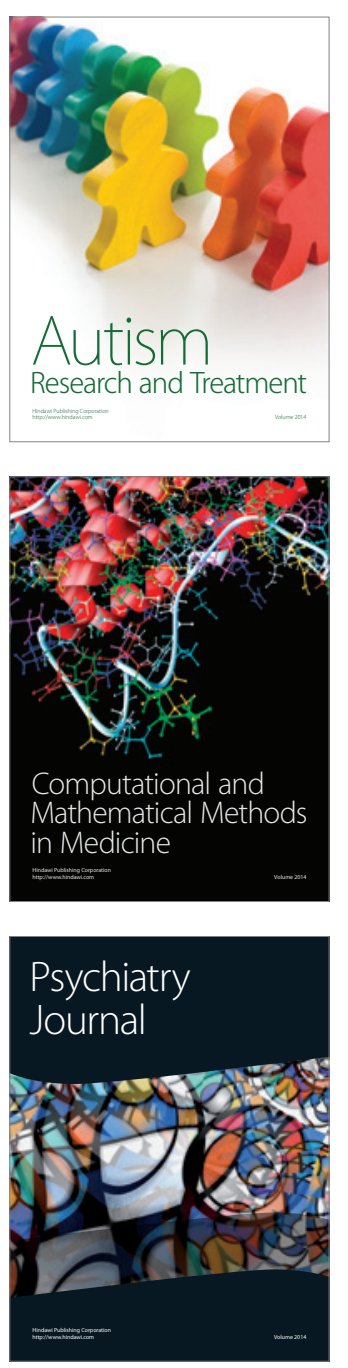
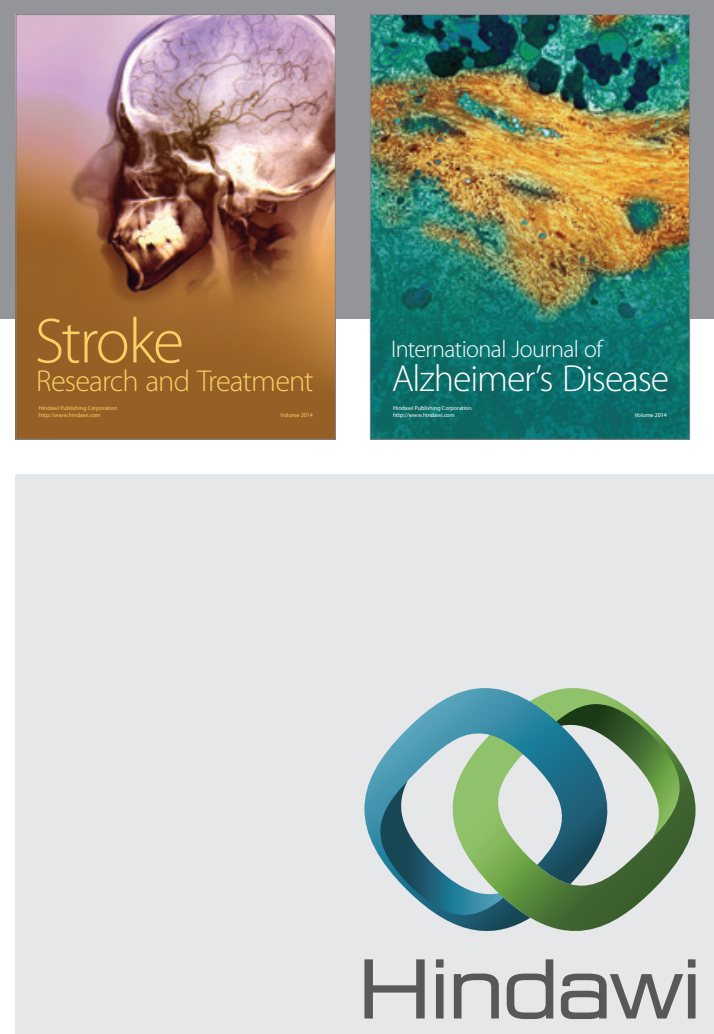

Submit your manuscripts at

http://www.hindawi.com
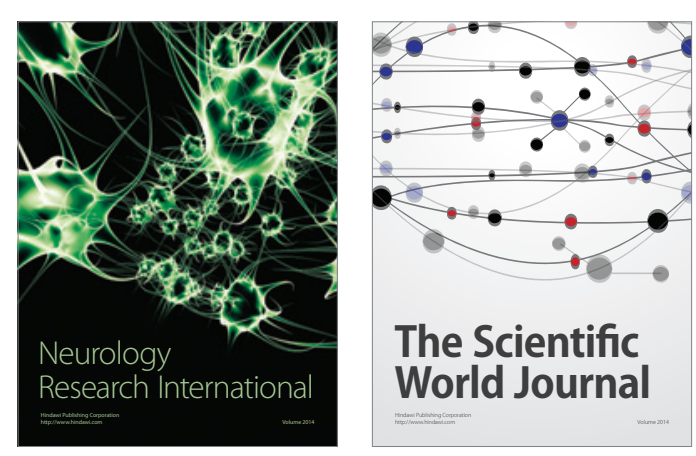

The Scientific World Journal

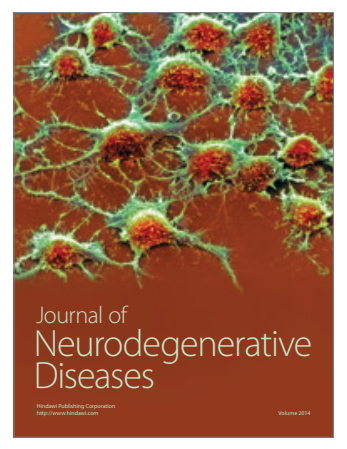

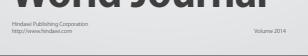

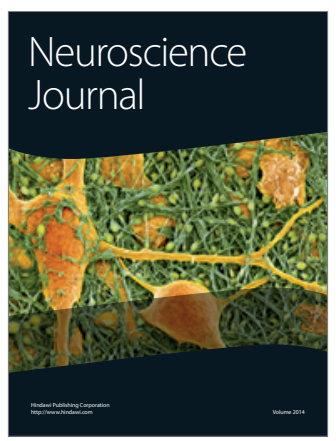

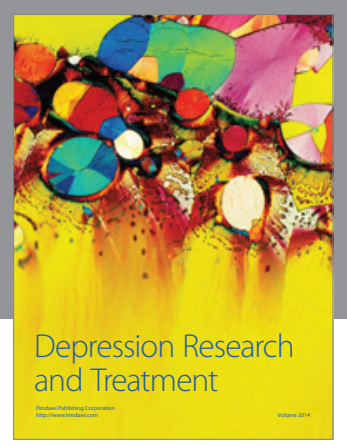
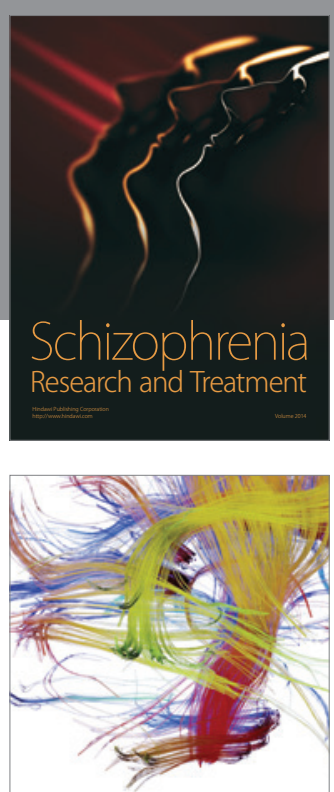

Brain Science

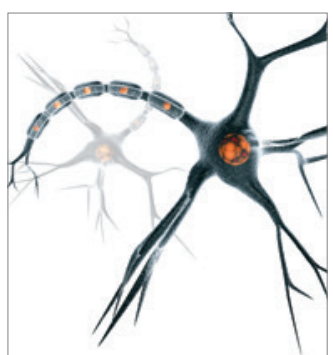

Neural Plasticity
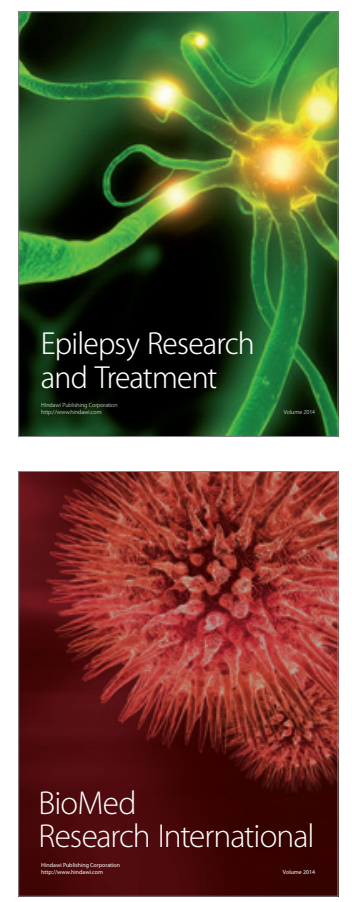

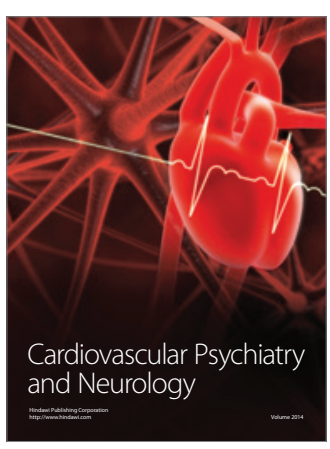

Parkinson's

Disease
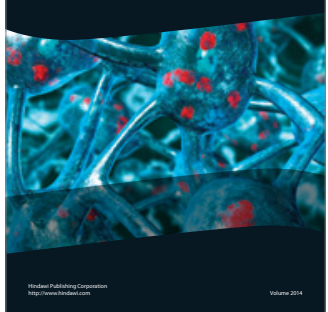